\title{
Furanocembranoid from the Okinawan soft coral Sinularia sp.
}

\author{
Misaki Nagasaka ${ }^{1}$, Kazuki Tani ${ }^{1}$, Keisuke Nishikawa² ${ }^{2}$ Riri Kinjo ${ }^{1}$ and Takahiro Ishii ${ }^{*}$ (i)
}

\begin{abstract}
One new furanocembranoid diterpene, 11-hydroxy- $\Delta^{12(13)}$-pukalide (1), along with six known secondary metabolites, 11 -acetoxy- $\Delta^{12(13)}$-pukalide (2), 13a-acetoxypukalide (3), pukalide (4), 3a-methoxyfuranocembranoid (5), $\Delta^{9(15)}$ africanene (6), and methyl (5'E)-5-( $\left(2^{\prime}, 6^{\prime}\right.$-dimethylocta-5', $7^{\prime}$-dienyl)furan-3-carboxylate (7) were isolated from the Okinawan soft coral Sinularia sp. Their chemical structures were elucidated based on spectroscopic analysis (FTIR, NMR, and HRESIMS), and the relative stereochemistry of $\mathbf{1}$ was determined by NOESY experiments and acetylation, which yielded derivative $\mathbf{2}$. In addition, compounds $\mathbf{1}$ and $\mathbf{7}$ exhibited toxicity in the brine shrimp lethality test.
\end{abstract}

Keywords: Soft coral, Sinularia sp., Furanocembranoid, Diterpene

\footnotetext{
*Correspondence: ishiit@agr.u-ryukyu.ac.jp

${ }^{1}$ Department of Biosciences and Biotechnology, Faculty of Agriculture,

University of the Ryukyus, Senbaru 1, Nishihara, Okinawa 903-0213, Japan

Full list of author information is available at the end of the article
}

\section{说 Springer}




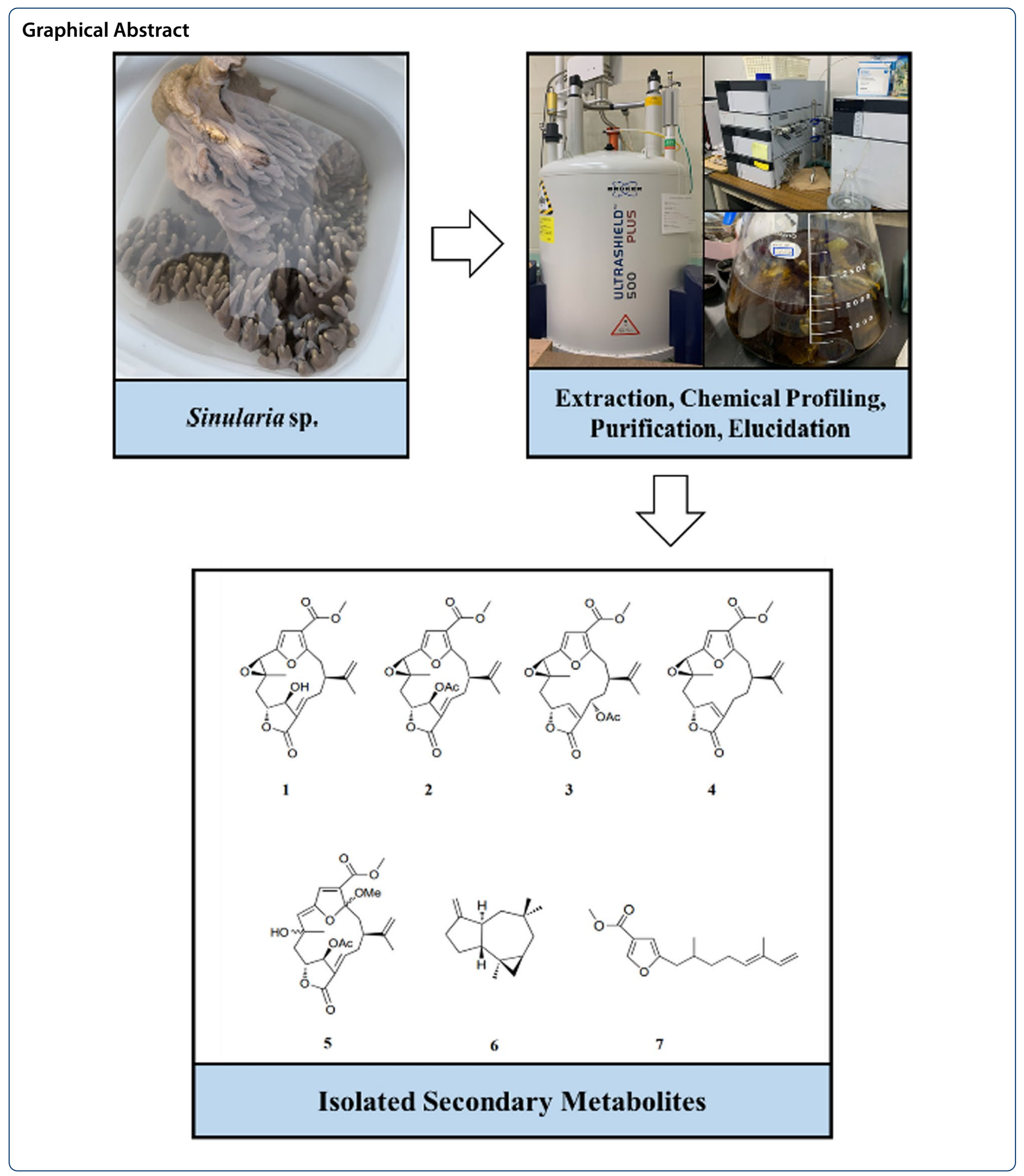

\section{Introduction}

The soft coral genus Sinularia (phylum Cnidaria, class Anthozoa, subclass Octocorallia, order Alcyonacea, family Alcyoniidae) is one of the most widely distributed soft coral genera in the tropics and subtropics, including Okinawa, Japan, inhabiting coral reefs or rocks in shallow waters $[1,2]$. Over the past 50 years, bioactive compounds, particularly various types of secondary metabolites such as sesquiterpenoids and diterpenoids, have been isolated from several species of the genus 
Sinularia, which makes them attractive targets for extensive chemical and biomedical research. In addition, more than 500 secondary metabolites of different biological origins have been identified in approximately $50 \mathrm{Sinu}$ laria species $[3,4]$. A significant number of these metabolites exhibit potent biological properties, including cytotoxic, antibacterial, antifungal, anti-inflammatory, and immunosuppressive activities [5-9].

This genus of Sinularia has also been studied for its chemical composition and biological activity in Okinawa, and various novel bioactive compounds have been isolated [10-12]. As part of our continuous research on bioactive compounds, a new compound, 11-hydroxy- $\Delta^{12(13)}$-pukalide (1), along with six known secondary metabolites, 11-acetoxy- $\Delta^{12(13)}$ pukalide (2), 13 $\alpha$-acetoxypukalide (3), pukalide (4), $3 \alpha$-methoxyfuranocembranoid $\quad(5), \quad \Delta^{9(15)}$-africanene (6), and methyl $\left(5^{\prime} E\right)-5-\left(2^{\prime}, 6^{\prime}\right.$-dimethylocta- $5^{\prime}, 7^{\prime}$-dienyl) furan-3-carboxylate (7) (Fig. 1), were isolated from the Okinawan soft coral Sinularia sp. In addition, we examined the antibacterial activities of Ralstonia solanacearum MAFF730131, along with toxic activities using the brine shrimp lethality test of the isolated compounds 1-7.

\section{Results and discussion}

Compound 1 was isolated as a yellow oil with $[\alpha]_{D}^{27}-215$ (c $0.1, \mathrm{CHCl}_{3}$ ). Its molecular formula was established as $\mathrm{C}_{21} \mathrm{H}_{24} \mathrm{O}_{7}$ based on HRESIMS, the positive ion at $\mathrm{m} / \mathrm{z} 389.1595[\mathrm{M}+\mathrm{H}]^{+}$(calcd 389.1600), indicating 10 degrees of unsaturation. The IR spectrum revealed the presence of hydroxy $\left(3471 \mathrm{~cm}^{-1}\right)$ and carbonyl functionalities $\left(1715 \mathrm{~cm}^{-1}\right)$. The ${ }^{1} \mathrm{H}$ and ${ }^{13} \mathrm{C}$ NMR spectra of 1 (Table 1) indicated the presence of 21 carbon signals, where their multiplicities were confirmed by DEPT and HSQC measurements as three methyls (including one methoxy), three $s p^{3}$ methylenes, four $s p^{3}$ methines (including three oxymethines), one $s p^{2}$ methylene, two $s p^{2}$ methines, and eight quaternary carbons. Comparison with the data of similar functionality in previous reports further supported that compound $\mathbf{1}$ is typical of a furanocembranoid [13-15]. In addition, the careful examination of ${ }^{1} \mathrm{H}$ and ${ }^{13} \mathrm{C}$ NMR spectra (Table 1) revealed that the structures of $\mathbf{1}$ and $\mathbf{2}$ were identical

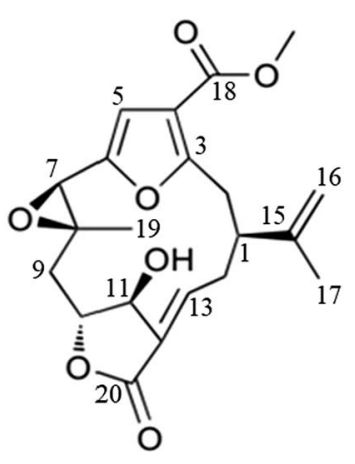

1

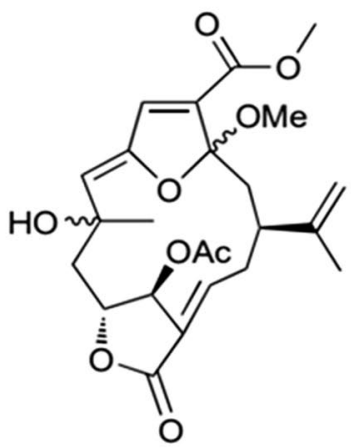

5

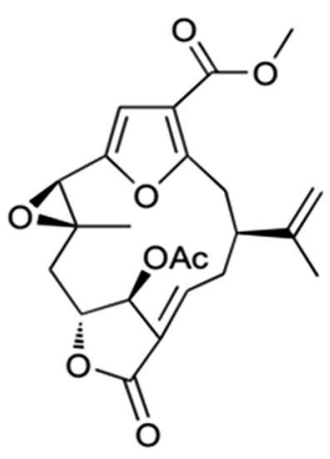

2

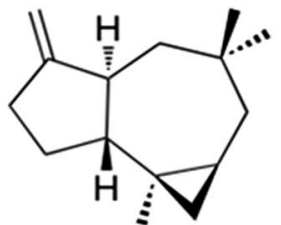

6

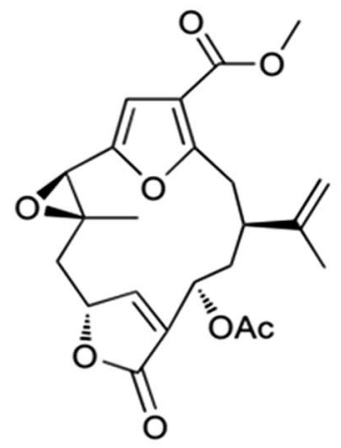

3

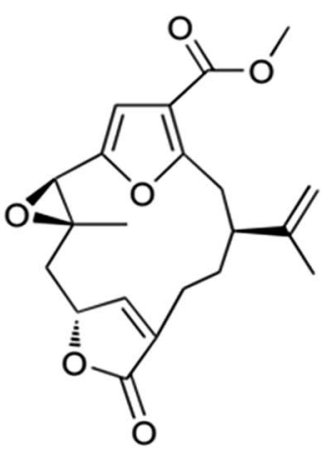

4<smiles>C=C/C(C)=C/CCC(C)Cc1cc(C(=O)OC)co1</smiles>

Fig. 1 Chemical structures of compounds 1-7 
Table $1{ }^{13} \mathrm{C} \quad$ NMR $(125 \mathrm{MHz})$ and ${ }^{1} \mathrm{H}$ NMR $(500 \mathrm{MHz})$ spectroscopic data for compound $\mathbf{1}$ ( $\delta$ in ppm and $J$ in $\mathrm{Hz}$ ) in $\mathrm{CDCl}_{3}$

\begin{tabular}{|c|c|c|}
\hline No & $\delta_{\mathrm{c}}$ & $\delta_{\mathrm{H}}$ (Mult. J) \\
\hline 1 & 41.0 & $2.87-2.90(\mathrm{~m})$ \\
\hline 2 & 30.7 & $\begin{array}{l}2.97(\mathrm{dd}, 15.5,5.2) \\
3.56(\mathrm{dd}, 15.5,5.2)\end{array}$ \\
\hline 3 & 160.5 & - \\
\hline 4 & 114.3 & - \\
\hline 5 & 108.1 & $6.35(d, 1.0)$ \\
\hline 6 & 147.9 & - \\
\hline 7 & 54.4 & $3.89(d, 1.0)$ \\
\hline 8 & 56.9 & - \\
\hline 9 & 40.8 & $\begin{array}{l}1.85(\mathrm{dd}, 15.2,3.6) \\
2.42(\mathrm{dd}, 15.2,3.6)\end{array}$ \\
\hline 10 & 83.6 & $4.59(t, 3.6)$ \\
\hline 11 & 72.3 & $4.64(s)$ \\
\hline 12 & 128.4 & - \\
\hline 13 & 148.8 & $6.52(\mathrm{dd}, 11.4,2.8)$ \\
\hline 14 & 30.5 & $\begin{array}{l}2.60(\mathrm{ddd}, 17.6,8.5,2.8) \\
3.95(\mathrm{ddd}, 17.6,11.4,1.7)\end{array}$ \\
\hline 15 & 145.2 & - \\
\hline 16 & 112.5 & $\begin{array}{l}4.56(\mathrm{~s}) \\
4.82(\mathrm{~s})\end{array}$ \\
\hline 17 & 23.4 & $1.68(s)$ \\
\hline 18 & 164.0 & - \\
\hline 19 & 21.5 & $1.10(\mathrm{~s})$ \\
\hline 20 & 169.0 & - \\
\hline OMe & 51.4 & $3.73(s)$ \\
\hline
\end{tabular}

except for the replacement of an acetoxy group at C-11 in $\mathbf{2}$ by a hydroxy group in $\mathbf{1}$.

The ${ }^{1} \mathrm{H}-{ }^{1} \mathrm{H}$ COSY (Fig. 2) experiment indicated two sequences of correlated protons, $\mathrm{H}-\mathrm{C}(13) / \mathrm{H}_{2}-\mathrm{C}(14) / \mathrm{H}-$ $\mathrm{C}(1) / \mathrm{H}_{2}-\mathrm{C}(2)$, and $\mathrm{H}_{2}-\mathrm{C}(9) / \mathrm{H}-\mathrm{C}(10) / \mathrm{H}-\mathrm{C}(11)$. The skeleton of compound $\mathbf{1}$ was deduced a furanocembranoid diterpene with a $\gamma$-lactone moiety in the HMBC experiment (Fig. 2) of $\mathrm{H}_{2}-2$ to $\mathrm{C}-3$ and C-4; $\mathrm{H}-5$ to $\mathrm{C}-4$ and C-6; $\mathrm{H}-7$ to $\mathrm{C}-5$ and $\mathrm{C}-6$; $\mathrm{H}-10$ to $\mathrm{C}-20 ; \mathrm{H}-11$ to $\mathrm{C}-12, \mathrm{C}-13$, and $\mathrm{C}-20 ; \mathrm{H}_{3}-19$ to $\mathrm{C}-7, \mathrm{C}-8$, and $\mathrm{C}-9$. In addition, the HMBC spectra of $\mathrm{H}_{2}-16$ to $\mathrm{C}-1, \mathrm{C}-15$, and $\mathrm{C}-17 ; \mathrm{H}_{3}-17$ to $\mathrm{C}-1, \mathrm{C}-15$, and $\mathrm{C}-16$ confirmed the position of the isopropyl group.

The relative stereochemistry of $\mathbf{1}$ was deduced from the NOESY correlation and comparison of its NMR spectrum, coupling constant, and NOE correlation with those of known analogs. The coupling constant $\left(J_{10,11}\right.$ $\approx 0 \mathrm{~Hz}$ ) suggested that the hydrogens were disposed to each other with a dihedral angle of $90^{\circ}$ between $\mathrm{H}-10$ and $\mathrm{H}-11$. This confirmed the trans orientation of $\mathrm{H}-10$ and $\mathrm{H}-11$ [16]. The NOE correlations for $\mathrm{H}-11$

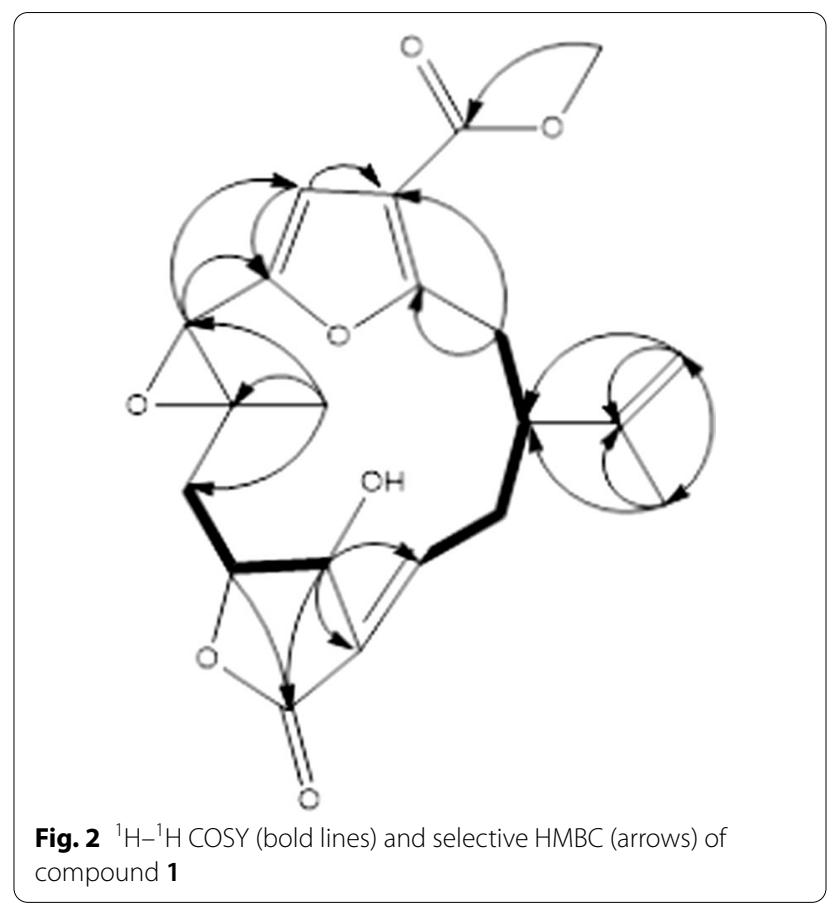

and $\mathrm{H}-13$ indicated that the double bond between $\mathrm{C}-12$ and $\mathrm{C}-13$ was in the $(Z)$-configuration. Furthermore, the steric structure of compound $\mathbf{1}$ was determined because the coupling constants of compounds 1 and 2 were identical. In addition, the ${ }^{1} \mathrm{H}$ and ${ }^{13} \mathrm{C}$ NMR spectra of acetylated compound $\mathbf{1}$ were consistent with those of compound 2 . Thus, the relative stereochemistry of 1 was assigned to be the same as that of 2 . To determine the absolute configuration of natural product $\mathbf{1}$, the modified Mosher's analysis of $\mathbf{1}$ is ongoing in our laboratory.

The structures of known compounds were identified as 11-acetoxy- $\Delta^{12(13)}$-pukalide (2) [16], 13 $\alpha$-acetoxypukalide (3) [16], pukalide (4) [17], $3 \alpha$-methoxyfuranocembranoid $\quad$ (5) $\quad[18], \quad \Delta^{9(15)}$. africanene (6) [19], and methyl $\left(5^{\prime} E\right)-5-\left(2^{\prime}, 6^{\prime}-\right.$ dimethylocta-5 $5^{\prime}, 7^{\prime}$-dienyl)furan-3-carboxylate (7) [20], by comparing their spectroscopic data with those reported in the literature.

The antibacterial activities of compounds 1-7 were evaluated against the phytopathogens $R$. solanacearum MAFF730131. Unfortunately, none of the compounds exhibited any antibacterial activity. In addition, the toxicities of compounds 1-7 were tested against brine shrimp. Consequently, compounds $\mathbf{1}$ and 7 were toxic against Artemia salina with $\mathrm{LC}_{50} 47.5$ and $24.6 \mu \mathrm{g} / \mathrm{mL}$, respectively, whereas the other compounds exhibited negligible effects with $\mathrm{LC}_{50}>100 \mu \mathrm{g} / \mathrm{mL}$. 


\section{Experimental}

\subsection{General experimental procedures}

Optical rotation was measured using a P-1010 polarimeter (Jasco) in chloroform at $27{ }^{\circ} \mathrm{C}$. IR spectra were recorded on a FT/IR-6100 spectrometer (Jasco). NMR spectra were recorded on a $500 \mathrm{MHz}$ NMR AVANCE III (Bruker) using deuterated chloroform $\left(\mathrm{CDCl}_{3}\right)$ and deuterated benzene $\left(\mathrm{C}_{6} \mathrm{D}_{6}\right)$. MS spectra were obtained using a SYNAPT HDMS system (Waters). Preparative TLC was performed using silica gel plates (Merck Kieselgel 60 $\mathrm{F}_{254}$ ). Silica gel (Kanto Chemical, Silica gel $60 \mathrm{~N}$, spherical, neutral, 100-210 $\mu \mathrm{m}$ ) was used for column chromatography. Semi-preparative HPLC was performed on a Shimadzu HPLC system with a Cosmosil $\pi N A P$ $(10 \times 250 \mathrm{~mm})$ column.

\subsection{Animal materials}

Specimens of Sinularia sp. were collected from the coast of Minato-Machi (26 $\left.13^{\prime} 55^{\prime \prime} \mathrm{N}, 127^{\circ} 40^{\prime} 17^{\prime \prime} \mathrm{E}\right)$, Naha, Okinawa, Japan, on November 13, 2019. The voucher specimen was deposited at the Faculty of Agriculture, University of the Ryukyus.

\subsection{Extraction and isolation}

The soft coral Sinularia sp. specimens $(1.25 \mathrm{~kg}$, wet wt) were sliced and extracted with $100 \%$ methanol $(\mathrm{MeOH})$ for one week at $25{ }^{\circ} \mathrm{C}$. The resulting crude extract was concentrated in vacuo and partitioned between ethyl acetate (EtOAc)/distilled water $\left(\mathrm{H}_{2} \mathrm{O}\right)$. The EtOAc fraction $(7.14 \mathrm{~g})$ was further partitioned with $n$-hexane/90\% $\mathrm{MeOH}$ to obtain $n$-hexane $(3.15 \mathrm{~g})$ and $90 \% \mathrm{MeOH}$ (3.42 g) fractions. The $n$-hexane and $90 \% \mathrm{MeOH}$ fractions were subjected to silica gel column chromatography elution with a gradient of $n$-hexane/EtOAc (9:1, 8:2, 7:3, $5: 5$, and $0: 10)$ to yield five fractions $1-5$. The $n$-hexane fraction 1 (28.4 $\mathrm{mg}$ ) was further separated by preparative TLC with $n$-hexane to yield 6 (22.6 mg). The MeOH fraction 2 (25.6 mg) yielded 7 (10.5 mg) after purification by preparative TLC using $n$-hexane/EtOAc (1:1) and toluene. $\mathrm{MeOH}$ fraction 4 (739.1 mg) was further separated by preparative TLC with $n$-hexane/EtOAc (1:1) to afford $2(15.7 \mathrm{mg})$. In addition, $\mathrm{MeOH}$ fraction $5(571.3 \mathrm{mg})$ was subjected to preparative TLC with $n$-hexane/EtOAc $(1: 1)$ and toluene/EtOAc (1:1) to yield $1(18.8 \mathrm{mg})$ and 3 (19.1 mg), which were further purified by preparative HPLC to yield $4(1.9 \mathrm{mg})$ and $5(2.4 \mathrm{mg})$. The isolation was performed using a $\pi$ NAP column measured at an UV wavelength of $210 \mathrm{~nm}$ under $70 \%$ and $80 \% \mathrm{MeOH}$.

\subsubsection{1-Hydroxy- $\Delta^{12(13)}$-pukalide (1)}

Yellow oil; $[\alpha]_{\mathrm{D}}^{27}-215$ (c 0.1, $\mathrm{CHCl}_{3}$ ); IR (liquid film) $v_{\max }$ $3477,2926,1746,1717,1442,1385,1229,1077,757 \mathrm{~cm}^{-1}$;
${ }^{1} \mathrm{H}$ NMR $\left(\mathrm{CDCl}_{3}, 500 \mathrm{MHz}\right) \delta_{\mathrm{H}}: 6.52(1 \mathrm{H}, \mathrm{dd}, J=11.4$, $2.8 \mathrm{~Hz}, \mathrm{H}-13), 6.35(1 \mathrm{H}, \mathrm{d}, J=1.0 \mathrm{~Hz}, \mathrm{H}-5), 4.82(2 \mathrm{H}, \mathrm{s}$, $\mathrm{H}-16)$, 4.64 (1H, s, H-11), 4.59 (1H, t, J=3.6 Hz, H-10), 4.56 (2H, s, H-16), 3.95 (2H, ddd, $J=17.6,11.4,1.7 \mathrm{~Hz}$, $\mathrm{H}-14), 3.89$ (1H, d, $J=1.0 \mathrm{~Hz}, \mathrm{H}-7), 3.73$ (3H, s, 18-OMe), $3.56(2 \mathrm{H}, \mathrm{dd}, J=15.5,5.2 \mathrm{~Hz}, \mathrm{H}-2), 2.97(2 \mathrm{H}, \mathrm{dd}, J=15.5$, $5.2 \mathrm{~Hz}, \mathrm{H}-2), 2.87-2.90(1 \mathrm{H}, \mathrm{m}, \mathrm{H}-1), 2.60$ (2H, ddd, $J=17.6,8.5,2.8 \mathrm{~Hz}, \mathrm{H}-14), 2.42(2 \mathrm{H}, \mathrm{dd}, J=15.2,3.6 \mathrm{~Hz}$, $\mathrm{H}-9), 1.85$ (2H, dd, J=15.2, $3.6 \mathrm{~Hz}, \mathrm{H}-9), 1.68(3 \mathrm{H}, \mathrm{s}$, $\mathrm{H}-17), 1.10$ (3H, s, H-19); ${ }^{13} \mathrm{C} \mathrm{NMR}\left(\mathrm{CDCl}_{3}, 125 \mathrm{MHz}\right)$ $\delta_{\mathrm{C}}: 169.0$ (C, C-20), 164.0 (C, C-18), 160.5 (C, C-3), 148.8 (CH, C-13), 147.9 (C, C-6), 145.2 (C, C-15), 128.4 (C, C-12), 114.3 (C, C-4), $112.5\left(\mathrm{CH}_{2}, \mathrm{C}-16\right), 108.1$ (CH, C-5), 83.6 (CH, C-10), $72.3(\mathrm{CH}, \mathrm{C}-11), 56.9(\mathrm{C}, \mathrm{C}-8), 54.4(\mathrm{CH}$, C-7), $51.4\left(\mathrm{CH}_{3}, 18-\mathrm{OMe}\right), 41.0(\mathrm{CH}, \mathrm{C}-1), 40.8\left(\mathrm{CH}_{2}\right.$, C-9), $30.7\left(\mathrm{CH}_{2}, \mathrm{C}-2\right), 30.5\left(\mathrm{CH}_{2}, \mathrm{C}-14\right), 23.4\left(\mathrm{CH}_{3}, \mathrm{C}-17\right)$, $21.5\left(\mathrm{CH}_{3}, \mathrm{C}-19\right)$; HRESIMS $\mathrm{m} / z 389.1595[\mathrm{M}+\mathrm{H}]^{+}$ (calcd for $\mathrm{C}_{21} \mathrm{H}_{25} \mathrm{O}_{7}, 389.1600$ ).

\subsection{Acetylation of 11-hydroxy- $\Delta^{12(13)}$-pukalide (1)}

Compound 1 (1 mg) was acetylated with acetic anhydride $(72 \mu \mathrm{L})$ and 4-dimethylaminopyridine $(4 \mathrm{mg})$ in dichloromethane $\left(\mathrm{CH}_{2} \mathrm{Cl}_{2}\right)$. The mixture was stirred at $0{ }^{\circ} \mathrm{C}$ overnight, and thereafter partitioned with $\mathrm{CH}_{2} \mathrm{Cl}_{2} / \mathrm{H}_{2} \mathrm{O}$ to afford 2 (1 mg), which exhibited HRESIMS as the positive ion at $m / z 431.1706[\mathrm{M}+\mathrm{H}]^{+}\left(\right.$calcd for $\mathrm{C}_{23} \mathrm{H}_{27} \mathrm{O}_{8}$, 431.1706).

\subsection{Bioassay \\ 3.5.1 Antibacterial assay}

Ralstonia solanacearum was streaked onto casamino acids peptone glucose (CPG) agar (peptone $10.0 \mathrm{~g}$, casamino acids $1.0 \mathrm{~g}$, glucose $5.0 \mathrm{~g}$, agar $17.0 \mathrm{~g}$, and deionized water $1 \mathrm{~L}$ ) from $-80{ }^{\circ} \mathrm{C}$ glycerol stocks and grown at $30{ }^{\circ} \mathrm{C}$ for $48 \mathrm{~h}$ to obtain a single colony. It was transferred into CPG broth and grown at $28{ }^{\circ} \mathrm{C}$ with shaking at $225 \mathrm{rpm}$ for $48 \mathrm{~h}$ to the exponential growth phase (optical density at $660 \mathrm{~nm}\left[\mathrm{OD}_{660}\right]=0.1$ ) [21]. Its bacterial solution was added to Top agar (peptone $3.0 \mathrm{~g}$, casamino acids $0.3 \mathrm{~g}$, glucose $1.7 \mathrm{~g}$, agar $5.0 \mathrm{~g}$, and deionized water $1 \mathrm{~L}$ ) and poured onto CPG agar medium and allowed to solidify. The isolated compounds dissolved in $\mathrm{MeOH}(1 \mathrm{mg} / \mathrm{mL})$ were impregnated on sterile filter paper discs (6 $\mathrm{mm}$ disc diameter) and thereafter applied aseptically to the surface of the agar plates. Chloramphenicol was used as the positive control. The plates were subsequently incubated at $30{ }^{\circ} \mathrm{C}$ for $24 \mathrm{~h}$. Then, the diameters of the inhibition zone including the $6 \mathrm{~mm}$ disc diameter, were measured. Experiments were conducted in triplicate, and the results were presented as mean values [22]. 


\subsubsection{Brine shrimp toxicity assay}

The eggs of brine shrimp (Artemia salina) were hatched in artificial seawater (prepared by dissolving instant sea salt $(13.5 \mathrm{~g})$ in $450 \mathrm{~mL}$ of distilled water) at room temperature. After $48 \mathrm{~h}$, the phototropic nauplii were collected, and 10 shrimp were transferred to each sample vial using a pipette. The isolated compounds were bioassayed in $1.5 \mathrm{~mL}$ tubes containing $1 \mathrm{~mL}$ of 10 brine shrimps at a final concentration of $100 \mu \mathrm{g} / \mathrm{mL}$. After $24 \mathrm{~h}$, the number of surviving shrimp was counted, and only those compounds that exceeded $50 \%$ lethality were bioassayed again at final concentrations of 10,20 , and $50 \mu \mathrm{g} / \mathrm{mL}$. Dimethyl sulfoxide was used as a negative control. The mortality rate at each concentration was calculated to determine $\mathrm{LC}_{50}$ values. Experiments were conducted in triplicate, and the results were presented as mean values [23].

\section{Supplementary Information}

The online version contains supplementary material available at https://doi. org/10.1007/s13659-022-00330-7.

Additional file 1: Figure S1. ${ }^{1} \mathrm{H}$ NMR spectrum of 11-hydroxy- $\triangle^{12(13)}$ pukalide (1) in $\mathrm{CDCl}_{3}(500 \mathrm{MHz})$. Figure $\mathbf{S 2} .{ }^{13} \mathrm{C}$ NMR spectrum of 11-hydroxy- $\Delta^{12(13)}$-pukalide (1) in $\mathrm{CDCl}_{3}(125 \mathrm{MHz})$. Figure S3. DEPT135 spectrum of 11-hydroxy- $\Delta^{12(13)}$-pukalide (1) in $\mathrm{CDCl}_{3}$. Figure $\mathbf{S 4} .{ }^{1} \mathrm{H}-{ }^{1} \mathrm{H}$ COSY spectrum of 11-hydroxy- $\triangle^{12(13)}$-pukalide (1) in $\mathrm{CDCl}_{3}$. Figure $\mathbf{S 5}$. HSQC spectrum of 11-hydroxy- $\triangle^{12(13)}$-pukalide (1) in $\mathrm{CDCl}_{3}$. Figure $\mathbf{S 6}$. HMBC spectrum of 11-hydroxy- $\triangle^{12(13)}$-pukalide (1) in $\mathrm{CDCl}_{3}$. Figure S7. HRESIMS of 11-hydroxy- $\Delta^{12(13)}$-pukalide (1). Figure S8. IR spectrum of 11-hydroxy- $\Delta^{12(13)}$-pukalide (1).

\section{Acknowledgements}

We are grateful to Mr. Masahiro Wada (Faculty of Agriculture, University of the Ryukyus) for his guidance on the collection site of the soft corals. The authors would also like to thank Mr. Shinichi Gima (Center for Research Advancement and Collaboration, University of the Ryukyus) for the measurement of HRESIMS. Finally, we would like to thank Editage (www.editage.com) for English language editing.

\section{Authors' contributions}

$M N, K T$, and $\mathrm{TI}$ conceived and designed the research; $\mathrm{MN}$ and $\mathrm{KT}$ carried out the experiments and wrote the manuscript; KN performed and assited in chemical conversions; RK helped in the acquisition of samples and compounds; TI supervised the whole study and critically reviewed the manuscript. All authors read and approved the final manuscript.

\section{Declarations}

\section{Competing interests}

The authors declare no conflict of interest.

\section{Author details}

'Department of Biosciences and Biotechnology, Faculty of Agriculture, University of the Ryukyus, Senbaru 1, Nishihara, Okinawa 903-0213, Japan. ${ }^{2}$ Department of Chemistry, Graduate School of Science, Osaka City University, Osaka 558-8585, Japan.

Received: 20 December 2021 Accepted: 12 February 2022 Published online: 02 March 2022

\section{References}

1. Shoham E, Prohaska T, Barkay Z, Zitek A, Benayahu Y. Soft corals form aragonite-precipitated columnar spiculite in mesophotic reefs. Sci Rep. 2019;9:1241-9.

2. Fujita K, Aruga K, Humblet M, Nagai K. Depositional environments of well-sorted detrital limestone from the Minatogawa Formation in the southern part of Okinawa Island, the Ryukyu Archipelago, Japan. Isl Arc. 2018;27:e12247.

3. Tammam MA, Rárová L, Kvasnicová M, Gonzalez G, Emam AM, Mahdy A Strnad M, loannou E, Roussis V. Bioactive steroids from the red sea soft coral Sinularia polydactyla. Mar Drugs. 2020;18:632-47.

4. Yan X, Liu J, Leng X, Ouyang H. Chemical diversity and biological activity of secondary metabolites from soft coral genus Sinularia since 2013. Mar Drugs. 2021;19:335-59.

5. Qin GF, Tang XL, Sun YT, Luo XC, Zhang J, van Ofwegen L, Sung PJ, Li PL, $\mathrm{Li} G Q$. Terpenoids from the soft coral Sinularia sp. collected in Yongxing Island. Mar Drugs. 2018;16:127-41.

6. Phan CS, Ng SY, Kamada T, Vairappan CS. Two new lobane diterpenes from a bornean soft coral Sinularia sp. Nat Prod Commun. 2016;11:899-900

7. Kamada T, Phan CS, Hamada T, Hatai K, Vairappan CS. Cytotoxic and antifungal terpenoids from Bornean soft coral, Sinularia flexibilis. Nat Prod Commun. 2018;13:17-9.

8. Kamada T, Kang MC, Phan CS, Zanil II, Jeon YJ, Vairappan CS. Bioactive cembranoids from the soft coral Genus Sinularia sp. in Borneo. Mar Drugs. 2018;16:99-112.

9. Yang M, Li H, Zhang Q, Wu QH, Li G, Chen KX, Guo YW, Tang W, Li XW. Highly diverse cembranoids from the South China Sea soft coral Sinularia scabra as a new class of potential immunosuppressive agents. Bioorg Med Chem. 2019;27:3469-76.

10. Kusumi T, Uchida H, Ishitsuka MO, Yamamoto H, Kakisawa H. Alcyonin, a new cladiellane diterpene from the soft coral Sinularia flexibilis. Chem Lett. 1988;17:1077-8.

11. Ojika M, Islam MK, Shintani T, Zhang Y, Okamoto T, Sakagami Y. Three new cytotoxic acylspermidines from the soft coral, Sinularia sp. Biosci Biotechnol Biochem. 2003;67:1410-2.

12. Roy PK, Ashimine R, Miyazato H, Taira J, Ueda K. Endoperoxy and hydroperoxy cadinane-type sesquiterpenoids from an Okinawan soft coral, Sinularia sp. Arch Pharm Res. 2016;39:778-84.

13. Thomas SAL, von Salm JL, Clark S, Ferlita S, Nemani P, Azhari A, Rice CA, Wilson NG, Kyle DE, Baker BJ. Keikipukalides, furanocembrane diterpenes from the Antarctic deep sea octocoral Plumarella delicatissima. J Nat Prod. 2018;81:117-23.

14. Grote D, Dahse HM, Seifert K. Furanocembranoids from the soft corals Sinularia asterolobata and Litophyton arboreum. Chem Biodiversity. 2008:5:2449-56.

15. Venkateswarlu Y, Sridevi KV, Rao MR. New furanocembranoid diterpenes from the soft coral Sinularia maxima. J Nat Prod. 1999;62:756-8.

16. Bowden BF, Coll JC, Wright AD. Studies of Australian soft corals. XLIV. New diterpenes from Sinularia polydactyla (Coelenterata, Anthozoa, Octocorallia). Aust J Chem. 1989;42:757-63.

17. Missakian MG, Burreson BJ, Scheuer PJ. Pukalide, a furanocembranolide from the soft coral Sinularia abrupta. Tetrahedron. 1975;31:2513-5.

18. Kamel HN, Ferreira D, Garcia-Fernandez LF, Slattery M. Cytotoxic diterpenoids from the hybrid soft coral Sinularia maxima $\times$ Sinularia polydactyla. J Nat Prod. 2007;70:1223-7.

19. Kashman Y, Bodner M, Finer-Moore JS, Clardy J. $\Delta^{9}{ }^{9(15)}$-Africanene, a new sesquiterpene hydrocarbon from the soft coral Sinularia erecta. Experientia. 1980;36:891-1016.

20. Bowden BF, Coll JC, de Silva ED, de Costa MSL, Djura PJ, Mahendran M, Tapiolas DM. Studies of Australian soft corals. XXXI. Novel furanosesquiterpenes from several sinularian soft corals (Coelenterata, Octocorallia, Alcyonacea). Aust J Chem. 1983;36:371-6.

21. Milling A, Meng F, Denny TP, Allen C. Interactions with hosts at cool temperatures, not cold tolerance, explain the unique epidemiology of Ralstonia solanacearum race 3 biovar 2. Phytopathology. 2009;99:1127-34.

22. Zhao X, Mei W, Gong M, Zuo W, Bai H, Dai H. Antibacterial activity of the flavonoids from Dalbergia odorifera on Ralstonia solanacearum. Molecules. 2011;16:9775-82

23. Putra MY, Murniasih T, Swasono RT, Wibowo JT, Saputri ANC, Widhiana MR, Arlyza IS. Secondary metabolites and their biological activities in 
Indonesian soft coral of the genus Lobophytum. Asian Pac J Trop Biomed. 2016;6:909-13.

\section{Publisher's Note}

Springer Nature remains neutral with regard to jurisdictional claims in published maps and institutional affiliations.

\section{Submit your manuscript to a SpringerOpen ${ }^{\circ}$ journal and benefit from:}

- Convenient online submission

- Rigorous peer review

- Open access: articles freely available online

- High visibility within the field

- Retaining the copyright to your article

Submit your next manuscript at $\boldsymbol{\nabla}$ springeropen.com 